\title{
https://doi.org/10.46813/2020-130-119 \\ APPLICATION OF DIELECTRIC BARRIER DISCHARGE AND PLASMA-CHEMICAL REACTOR FOR WATER PURIFICATION FROM NH $\mathrm{NH}_{4} \mathrm{OH}$
}

\author{
V.S. Taran ${ }^{1}$, I.E. Garkusha ${ }^{1}$, V.V. Krasnyj ${ }^{1}$, A.V. Taran ${ }^{1}$, A.S. Lozina', \\ O.G. Chechelnitskyi ${ }^{1}$, I.M. Boldyriev ${ }^{2}$, S.P. Romaniuk ${ }^{3}$ \\ ${ }^{1}$ Institute of Plasma Physics NSC “Kharkov Institute of Physics and Technology”, Kharkiv, Ukraine;
${ }^{2}$ Public Joint Stock Company “HARTRON”, Kharkiv, Ukraine;
${ }^{3}$ Petro Vasylenko Kharkiv National Technical University of Agriculture, Kharkiv, Ukraine
} E-mail:avtaran@ukr.net

Water purification from ammonium hydroxide was carried out by using two methods of processing: treatment with ozone generated by a dielectric barrier discharge (DBD) as well as processing in plasma-chemical reactor equipped with a water electrode and a diaphragm, where the main oxidation factors were $\mathrm{OH}$ hydroxyl radicals. The volume of the treated aqueous solution was $300 \mathrm{ml}$ and the $\mathrm{NH}_{4} \mathrm{OH}$ concentration was $0.025 \mathrm{ml}$ in both cases. The phenolphthalein test was used for visual analysis of the content of an aqueous solution of ammonia in water. The ozone concentration was about $5.8 \mathrm{mg} / \mathrm{l}$ in water with ozone injection from an ozone generator and $0.7 \mathrm{mg} / \mathrm{l} \mathrm{in}$ a plasma-chemical reactor, respectively. The analysis of $\mathrm{OH}$ and $\mathrm{NO}$ radicals in the water-air gap of the plasmachemical reactor was carried out using a spectrometer operated in the range of $200 \ldots 800 \mathrm{~nm}$.

PACS: 52.80.Hc, 41.75.Lx, 41.60.Bq

\section{INTRODUCTION}

Water purification from ammonia is an urgent problem at various industrial and agricultural facilities, in artificial reservoirs and pools. Ammonia can be present in water in two forms, either ammonium hydroxide $\left(\mathrm{NH}_{3} * \mathrm{H}_{2} \mathrm{O}\right.$ or more common $\left.\mathrm{NH}_{4} \mathrm{OH}\right)$ or as the ammonium ion $\left(\mathrm{NH}_{4}\right)$. The total sum of the concentrations of ammonium and ammonia is called total ammonia nitrogen (TAN). The source of ammonia in water is salts and dissolved ammonia as well as nitrogen-containing substances resulting from the decomposition of protein compounds. Ammonia is a colorless gas, readily soluble in water, with a characteristic odor, has a toxic effect on the aquatic flora and fauna and can occur in an aqueous solution at a $\mathrm{pH}$ of less than 8 in the form of ammonia, at a $\mathrm{pH}$ of more than 11 in the form of ammonium, between $\mathrm{pH}$ 8 ...11 both ammonium and ammonia exist. Taking into consideration the environmental hazard of ammonia, a number of methods are aimed at its removal, both in air and in the aquatic environment.

Today, there are various methods which can significantly reduce the ammonia content in water. Known methods of chemical precipitation, purging, desorption and adsorption are usually used for the purification of ammonia-nitrogen wastewater with a low concentration.

The chemical precipitation method is designed to reduce the solubility of ammonia nitrogen in water by forming an insoluble salt. The purge method typically uses $\mathrm{NaOH}$ to adjust the $\mathrm{pH}$ to basic wastewater and ammonia nitrogen can exist in the form of free ammonia $\left(\mathrm{NH}_{3}\right)$. Then, ammonia nitrogen leaves the aqueous solution and exits into the atmosphere. The removal of ammonia by desorption is a process that is often considered as one of the possible ways of wastewater ISSN 1562-6016. BAHT. 2020. №6(130)

PROBLEMS OF ATOMIC SCIENCE AND TECHNOLOGY. 2020, № 6. Series: Plasma Physics (26), p. 119-122. treatment, but it does not find wide practical application. In addition, to remove nitrogen from water, which exists in the wastewater in the form of free ammonia, ammonium salts and nitrites, it is possible to use the reduction of nitrates to molecular nitrogen in a biological way (denitrification). First, it is necessary to oxidize ammonia nitrogen into nitrites and nitrates (nitrification) [1]. However, biological nitrification layers are subject to significant fluctuations in efficiency, since nitrifying bacteria in the biofilter layers are sensitive to environmental disturbances and changes in working conditions, which are often associated with color, smell and taste problems and, in addition, worsen the biofilter function [2]. When removing nitrogen in the ammonium form, it is advisable to use ion-exchange filters, in particular, filtering waste water through loading from natural zeolites [3]. Free chlorine $\left(\mathrm{HOCl}^{+} \mathrm{OCl}^{-}\right)$is usually used in water and wastewater treatment to disinfect and remove ammonia. However, in addition to the desired effects, residual free chlorine can also have a number of undesirable ones: for example, it is toxic to organisms existing in the water, lowers the palatability of drinking water, and is aggressive in the industrial use of water. Thus, free chlorine should be removed from water or at least reduced in its content.

Ozone $\left(\mathrm{O}_{3}\right)$ is a strong oxidizing agent, especially in the presence of $\mathrm{OH}^{-}, \mathrm{H}_{2} \mathrm{O}_{2} / \mathrm{HO}^{-}, \mathrm{Fe}_{2}, \mathrm{UV}$, and other activators or accelerators of free radicals $[4,5]$. Under the influence of excited radicals and accelerators, ozone will cause a large number of hydroxyl radicals $(\mathrm{OH})$ in the reaction system, which will lead to chain reactions and then more reactive radicals will be produced.

Studies by Hoigne J. and Bader H. [6] showed that ozone-induced oxidation of ammonia in water can be the result of a direct reaction of ozone with ammonia, as 
well as reactions of hydroxyl radicals generated by the decomposition of ozone. The direct ozone reaction predominates at $\mathrm{pH}<9$, but in the presence of low concentrations of free ammonia this is a slow reaction. At $\mathrm{pH}>9$, the hydroxyl ionic and radical-catalyzed decomposition of ozone to a reactive intermediate hydroxyl radical determines the kinetics of ammonia oxidation. The reaction rate constant of the hydroxyl radical with ammonia is relatively small. Whenever the mechanism of hydroxyl radicals is activated, ammonia is easily protected by other dissolved substances, which also consume hydroxyl radicals.

According to De Pena and Olszyna [7, 8], $\mathrm{NH}_{3}$ can react with $\mathrm{O}_{3}$ to form ammonium nitrate $\left(\mathrm{NH}_{4} \mathrm{NO}_{3}\right)$. In these reaction processes, $\mathrm{NH}_{3}$ is first oxidized to nitric acid and then reacts with nitric acid to form $\mathrm{NH}_{4} \mathrm{NO}_{3}$. Xianping Luo, Qun Yan et al. [9] studied the purification process using the two-stage method of ozone oxidation of wastewater with ammonia nitrogen content (about $100 \mathrm{mg} / \mathrm{l}$ ). Also, the effect of the ozone flow rate and the initial $\mathrm{pH}$ on the removal of ammonia was investigated. It was determined that after the initial stage of ozone oxidation, the ammonia removal efficiency reached $59.32 \%$, and the $\mathrm{pH}$ decreased from 11 to 6.63 at an ozone flow rate of $1 \mathrm{l} / \mathrm{min}$, and after the second stage, the removal efficiency was more than $85 \%$. In [10], when treating ammonia in air, it was shown that $1.8 \mathrm{mg}$ of $\mathrm{O}_{3}$ is necessary for the oxidation of $1 \mathrm{mg}$ of $\mathrm{NH}_{3}$.

Considering the above mentioned, all methods have their own characteristics, but each of them has its own limitations or has different levels of investment in equipment, high operating costs, secondary pollution and other disadvantages [11-15]. Therefore, it is necessary to find effective, practical methods for removing ammonia. In so doing, considerable interest is given to non-equilibrium low-temperature plasma and, in particular, dielectric barrier discharge (DBD) used for ammonia removal from aqueous medium.

\section{EXPERIMENTAL SETUP 1.1. OZONE REACTOR BASED ON DBD}

A reactor based on a dielectric barrier discharge with air-cooled plane-parallel electrodes was used as an ozone generator (Fig. 1).

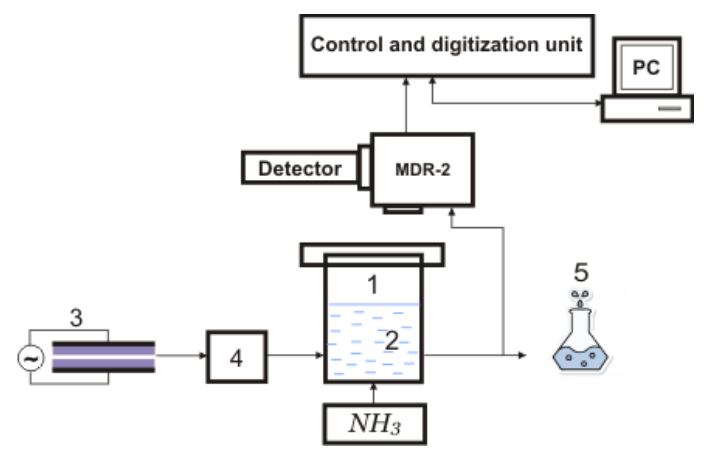

Fig. 1. Scheme of $\mathrm{NH}_{4} \mathrm{OH}$ oxidation with ozone in $\mathrm{DBD}$ :

1 - stainless steel container with plexiglass cover;

2 -water; 3 -ozone reactor based on a dielectric barrier discharge; 4 -ozone concentration meter of M454 DIN type;5 - system for obtaining a solution for analysis
Glass with $\varepsilon=6$ was used as a dielectric. The reactor is powered by a high-voltage pulse supply of $7 \mathrm{kV}$ and power consumption comprised $10 \mathrm{~W}$. The ozone concentration at the reactor outlet was $25 \mathrm{mg} / \mathrm{l}$ at a dry air flow rate of $0.2 \mathrm{mg} / \mathrm{l}$. The concentration of $\mathrm{NH}_{4} \mathrm{OH}$ was $0.025 \mathrm{ml}$. $\mathrm{NH}_{4} \mathrm{OH}$ treatment was carried out in a stainless steel container with a volume of $0.5 \mathrm{l}$; the ozone concentration in water without ammonia was $5.8 \mathrm{mg} / 1$ at a water temperature of $20^{\circ} \mathrm{C}$.

\subsection{PLASMA-CHEMICAL REACTOR}

A diaphragm discharge was used to generate ozone in a plasma-chemical reactor. The $\mathrm{NH}_{4} \mathrm{OH}$ solution was processed inside the discharge chamber - a container made of a dielectric material with a separating dielectric diaphragm membrane having holes of $1 \mathrm{~mm}$ in diameter. A general view of the diaphragm reactor is shown in Fig. 2. The diaphragm reactor was described in more detail in [16]. The ozone concentration in water was determined by using an automated stand equipped with MDR-2 monochromator and a photomultiplier tube (PMT) and amounted to about $0.7 \mathrm{mg} / \mathrm{l}$. The $\mathrm{NH}_{4} \mathrm{OH}$ concentration was $0.025 \mathrm{ml}$.

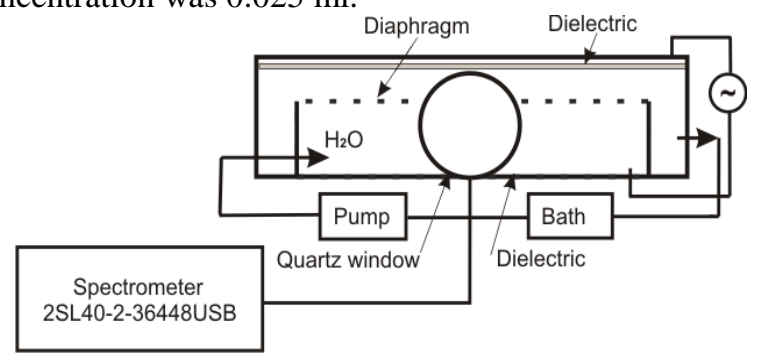

Fig. 2. Schematic view of plasma-chemical reactor and diaphragm discharge

\subsection{DISCUSSION}

Plasma in an oxygen-containing environment in contact with an aqueous solution is a source of such strong oxidants as $\mathrm{O}, \mathrm{OH}, \mathrm{HO}_{2}, \mathrm{H}_{2} \mathrm{O}_{2}, \mathrm{O}_{3}$, which, penetrating into the solution, lead to the destruction of organic pollutants. Regardless of the type of discharge, the emission spectrum contains bands of $\mathrm{N}_{2}, \mathrm{OH}$, and $\mathrm{NO}$ molecules and lines of $\mathrm{O}$ and $\mathrm{H}$ atoms during a discharge in air and oxygen [17].

The performed spectroscopic studies in the range of $200 \ldots 800 \mathrm{~nm}$ in the water-air gap of the discharge revealed the presence of $\mathrm{OH}$ and $\mathrm{NO}$ lines in the waterair gap (Fig. 3).

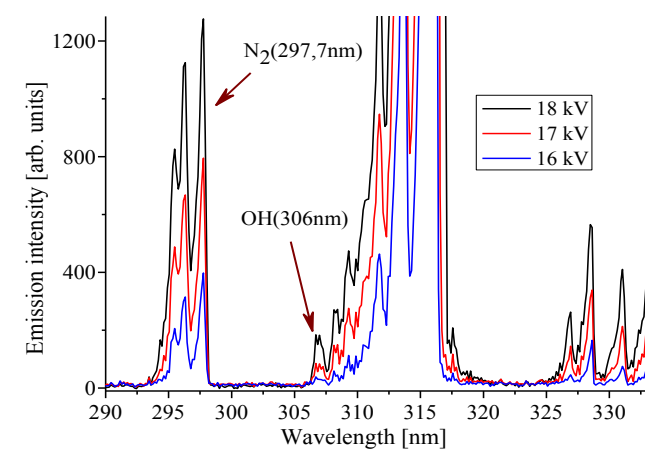

Fig. 3. The emission spectrum of the discharge in the air-water gap depending on the applied voltage 
The change in the intensity of the $\mathrm{OH}$ and $\mathrm{N}_{2}$ peaks in the discharge was also obtained depending on the applied voltage. We assume that the presence of hydroxyl radicals in the discharge has a significant effect on the treated impurities in water, because this ozone concentration may not be enough for $\mathrm{NH}_{4} \mathrm{OH}$ oxidation.

To visually determine the oxidation of the $\mathrm{NH}_{4} \mathrm{OH}$ solution, a phenolphthalein sample was used, which stains the solution in a raspberry color. When the $\mathrm{NH}_{4} \mathrm{OH}$ solution was treated with a diaphragm discharge, coloration was not observed after $10 \mathrm{~min}$ of treatment, and when treated with ozone, which was generated by a dielectric barrier discharge after $20 \mathrm{~min}$. The absence of coloration confirms the fact that the solution is not alkaline. Fig. 4 shows the change in the color of the $\mathrm{NH}_{4} \mathrm{OH}$ solution when using a phenolphthalein sample (a - during oxidation in a diaphragm discharge; $b$ - during oxidation with ozone generated by the DBD reactor).
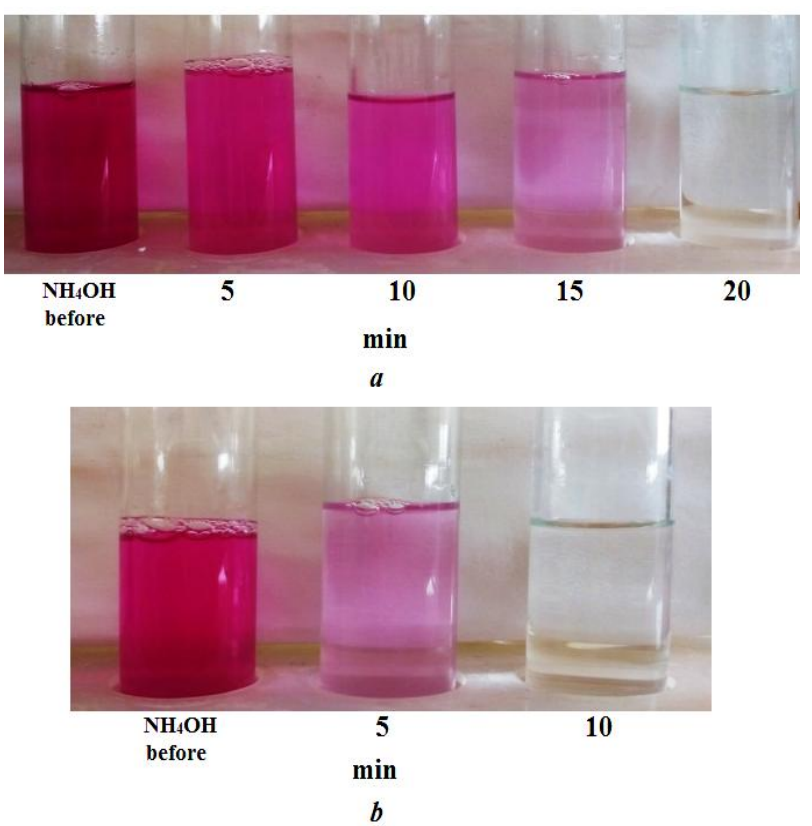

Fig. 4. Visual observation of $\mathrm{NH}_{4} \mathrm{OH}$ removal by color change during oxidation in a-diaphragm discharge, $b-D B D$

For a more accurate determination of the oxidation state of $\mathrm{NH}_{4} \mathrm{OH}$ in ozone, we used a method for determining the concentration of ozone in water on an automated stand using an MDR-2 monochromator (LOMO, Russia) and a photomultiplier tube (PMT). First, in the presence of $\mathrm{NH}_{4} \mathrm{OH}$ in water, the device recorded the absence of ozone in the water. When the ozone concentration started to increase, this meant that ozone was present in the water and $\mathrm{NH}_{4} \mathrm{OH}$ was oxidized. Ozone concentration was recorded every $5 \mathrm{~min}$. With a diaphragm discharge, small values of the ozone concentration began to be recorded after $10 \mathrm{~min}$ of treatment, and with DBD - after $20 \mathrm{~min}$. As a result it was calculated that $4 \mathrm{~g}$ of $\mathrm{O}_{3}$ generated by $\mathrm{DBD}$ is sufficient for the oxidation of $1 \mathrm{ml}$ of $\mathrm{NH}_{4} \mathrm{OH}$. For the oxidation of $1 \mathrm{ml}$ of $\mathrm{NH}_{4} \mathrm{OH}$ in a plasma-chemical reactor, this device must be in operation for at least $6 \mathrm{~h}$.

\section{CONCLUSIONS}

Two methods of water purification from $\mathrm{NH}_{4} \mathrm{OH}$ are proposed: treatment with ozone generated by DBD and plasma-chemical treatment. A comparison of the kinetics of their oxidative processes is also given. The phenolphthalein sample was used to visually observe the $\mathrm{NH}_{4} \mathrm{OH}$ oxidation process. The change in the color of $\mathrm{NH}_{4} \mathrm{OH}$ upon treatment with ozone indicated the oxidation process sequence. As a result of the work carried out, it was calculated that for the oxidation of $1 \mathrm{ml}$ of $\mathrm{NH}_{4} \mathrm{OH}, 4 \mathrm{~g}$ of $\mathrm{O}_{3}$ is sufficient, which is generated by DBD or at least $6 \mathrm{~h}$ of operation of the plasma-chemical reactor.

\section{REFERENCES}

1. V.I. Grinevich, A.A. Gushin, N.A. Plastinina // Izvestia VUZ. Chemistry and chemical technology. 2009, v. 52, № 2, p. 130-134.

2. D.W. Graham, C.W. Knapp, E.S. Vleck, K. Bloor, T.B. Lane, C.E. Graham. Experimental demonstration of chaotic instability in biological nitrification// ISME J. 2007, № 1, p. 385-393.

3. P.J. Udeh. A Guide to Healthy Drinking Water // Universe: «Bloomington», IN, USA, 2004.

4. B. Li, J.Y. Zhao, J.F. Lu. Numerical study of the simultaneous oxidation of $\mathrm{NO}$ and $\mathrm{SO}_{2}$ by ozone //Int. J. Environ. Res. Public Health. 2015, № 12, p. 1595-1611. 5. Y. Ishizuka, M. Tokumura, A. Mizukoshi, M. Miyuki Noguchi, Y. Yanagisawa. Measurement of Secondary Products during oxidation reactions of terpenes and ozone based on the Prt-MS analysis: Effects of coexistent carbonyl compounds // Int. J. Environ. Res. Public Health. 2010, № 7, p. 3853-3870.

6. J. Hoigné, H. Bader. Ozonation of water: kinetics of oxidation of ammonia by ozone and hydroxyl radicals // Environmental Science and Technology.1978, v. 12, p. 79-84.

7. R.G.De Pena, K. Olszyna, J. Heicklen. Kinetics of Particle Growth. I. Ammonium Nitrate from the Ammonia-Ozone Reaction // Phys. Chem. 1973, № 77, p. 438-443.

8. K.J. Olszyna, J. Heicklen. Reaction of Ozone with Ammonia// Adv. Chem. Series. 1972, p. 191-210.

9. Luo Xianping, Yan Qun, Wang Chunying, Luo Caigui, Zhou Nana, Chensheng Jian. Treatment of Ammonia Nitrogen Wastewater in Low Concentration by Two-Stage Ozonization // Int. J. Environ. Res. Public Health. 2015, v. 12.

10. V.S. Taran, V.V. Krasnyj, A.S. Lozina, O.G. Chechelnitskyi, A.V. Schebetun. Investigation of ozone decay half-life in dependence of temperature and humidity as $\mathrm{H}_{2} \mathrm{~S}$ and $\mathrm{NH}_{3}$ oxidation mechanism // Problems of Atomic Science and Technology. Series «Plasma Physics». 2017, № 1, p. 244-246.

11. I. Mahamudur, P. Rajkishore. Synthesis and physicochemical characterization of $\mathrm{Zn} / \mathrm{Al}$ chloride layered double hydroxide and evaluation of its nitrate removal efficiency // Desalination. 2010, № 256, p. 120-128. 
12. H. Yang, H. Cheng. Controlling nitrite level in drinking water by chlorination and chloramination // Sep. Purif. Technol. 2007, № 56, p. 392-396.

13. Z. Guo, Z. Zheng, C. Gu, Y. Zheng. Gamma irradiation-induced removal of low-concentration nitrite in aqueous solution // Radiat. Phys. Chem. 2008, № 77, p. 702-707.

14. G. Markou, D. Vandamme, K. Muylaert. Using natural zeolite for ammonia sorption from wastewater and as nitrogen releaser for the cultivation of Arthrospira platensis // Bioresour. Technol. 2014, № 155 , p. 373-378.

15. H.Wang, K.G. Zhou. The research development on the treatment of ammonia-nitrogen wastewater // Ind. Saf. Environ. Prot. 2006, № 32, p 7-9.
16. V.S. Taran, V.V. Krasnyj, A.S. Lozina, O.M. Shvets. Investigation of pulsed barrier discharge in water air gap // Problems of Atomic Science and Technology. Series «Plasma Physics». 2013, № 1, p. 249-251.

17. E.S. Bobkova, Ya.V. Khodor, O. N. Kornilova, V.V. Rybkin. The chemical composition of the plasma of a dielectric barrier discharge of atmospheric pressure with a liquid electrode // Thermophysics of high temperatures. 2014, v. 52, № 4, p. 535-542.

Articlereceived 05.10.2020

\title{
ПРИМЕНЕНИЕ ДИЭЛЕКТРИЧЕСКОГО БАРЬЕРНОГО РАЗРЯДА И ПЛАЗМОХИМИЧЕСКОГО РЕАКТОРА ДЛЯ ОЧИСТКИ ВОДЫ ОТ $\mathrm{NH}_{4} \mathrm{OH}$
}

\author{
В.С. Таран, И.Е. Гаркуша, В.В. Красный, А.В. Таран, А.С. Лозина, О.Г. Чечельницкий, \\ И.Н. Болдырев, С.П. Романюк
}

\begin{abstract}
Очистка воды от гидроксида аммония проводилась двумя способами: обработкой озоном, генерируемым диэлектрическим барьерным разрядом (ДБР), и обработкой в плазмохимическом реакторе, оборудованном водяным электродом и диафрагмой, в котором основным фактором окисления являлись гидроксильные радикалы ОН. Объем обработанного водного раствора составлял 300 мл, а концентрация $\mathrm{NH}_{4} \mathrm{OH}$ составляла 0,025 мл в обоих случаях. Фенолфталеиновый тест использовали для визуального анализа содержания водного раствора аммиака в воде. Концентрация озона составляла около 5,8 мг/л в воде при вводе озона из генератора озона и 0,7 мг/л в плазмохимическом реакторе соответственно. Анализ радикалов ОН и $\mathrm{NO}$ в водно-воздушном зазоре плазмохимического реактора проводился на спектрометре, работающем в диапазоне 200...800 нм.
\end{abstract}

\section{ЗАСТОСУВАННЯ ДІЕЛЕКТРИЧНОГО БАР'ЄРНОГО РОЗРЯДУ І ПЛАЗМОХІМІЧНОГО РЕАКТОРУ ДЛЯ ОЧИЩЕННЯ ВОДИ ВІД $\mathrm{NH}_{4} \mathrm{OH}$}

\author{
В.С. Таран, І.С. Гаркуиа, В.В. Красний, А.В. Таран, А.С. Лозина, О.Г. Чечельницький, \\ I.М. Болдирев, С.П. Романюк
}

Очищення води від гідроксиду амонію проводилося двома способами: обробкою озоном, що генерується діелектричним бар'єрним розрядом (ДБР), і обробкою в плазмохімічному реакторі, обладнаному водяним електродом і діафрагмою, в якому основним чинником окислення були гідроксильні радикали ОН. Обсяг обробленого водного розчину становив 300 мл, а концентрація $\mathrm{NH}_{4} \mathrm{OH}$ становила 0,025 мл в обох випадках. Фенолфталеїновий тест використовували для візуального аналізу змісту водного розчину аміаку у воді. Концентрація озону становила близько 5,8 мг/л у воді при введенні озону з генератора озону і 0,7 мг/л в плазмохімічному реакторі відповідно. Аналіз радикалів ОН i NO в водно-повітряному проміжку плазмохімічного реактора проводився на спектрометрі, що працює в діапазоні $200 \ldots 800$ нм. 